\title{
Finding a Third Space: A Postcolonial Comparative study of Verdecchia's Fronteras Americanas and Fugard's Sizwe Basnsi is Dead
}

\author{
Dr. Rasha F.M.Hamza \\ Lecturer of English Literature, Faculty of Al-Alsun \\ (Languages), Luxor University
}

\begin{abstract}
:
Post colonialism is one the most influential literary theories of the Twentieth Century. It refers to the literary products by the people of the ex-colonies. Additionally, the term is also extended to include the literature produced by the people of the ex-colonies of Europe, both before and after political independence. This type of literature gives a faithful representation of the suffering of the people under the yoke of colonialism. Homi K. Bhabha is one of the most prominent critics of the post-colonial discourse. Bhabha's theory revolves around answering one question: how can the product of a hybrid culture create his or her own cultural identity? He comes to the conclusion that this product a hybrid culture can actually produce his own new cultural identity. This can occur out of the notion of "in-between spaces". Furthermore, Bhabha elaborates that in order to avoid any type of cultural clash between the colonizer and the colonized; they should meet in a third space. Both the colonizer and the colonized can meet together to discuss their cultural differences in this third space. Eventually, this will create a culture that is a mixture of both the colonizer and the colonized. The purpose of this paper is to investigate how Verdecchia's Fronteras Americanas (American Borders) and Fugard's Sizwe Basnsi is Dead, represent Homi K. Bhabha's notion of third space.
\end{abstract}

\section{Key Words:}

Post colonialism, Homi K. Bhabha, Third Space, Gullirmo Verdecchia, Athol Fugard. 
البحث عن مساحة ثالثة : دراسة مقارنة و قراءة ما بعد كولونيالية لمسرحية جيليرمو فيرديكيا "الحدود الأمريكية" ومسرحية "سيزوي بانسي قد مات" ل أتول فوجارد

د. دشا فاروق محمود حمزة

مدرس الأدب الإنجليزى- قسم اللغة الإنجليزية_ كلية الألسن- جامعة الأقصر، مصرد.

ملخص البحث باللغة العربية: تعد نظرية ما بعد الكولونيالية واحدة من أكثر النظريات الأدبية تأثيرًا في القرن العشرين. فتلك النظرية تثير إلى الناتج الأدبي للشعوب التى قد سبة ستى استعمارها. بالإضافة إلى ذلك، فإن المصطلح قد امتد ليثمل ايضا الأدبيات التي أنتجتها شعوب المستعمرات السابقة في أوروبا، قبل الاستقلال السياسي وبعده. يعطي هذا النوع من

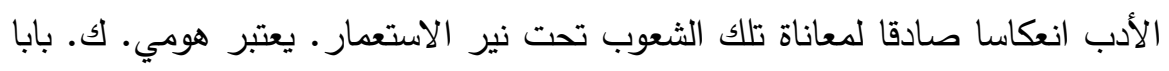

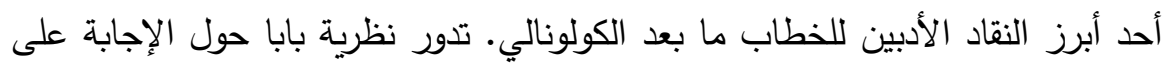

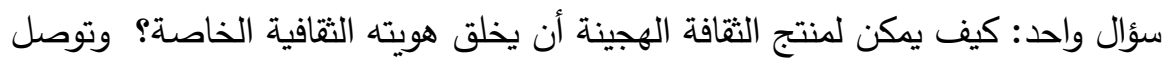
بابا إلى استنتاج مفاده أن هذا المنتج للثقافة الهجينة يستطيع أن ينتج هويته الثقافية

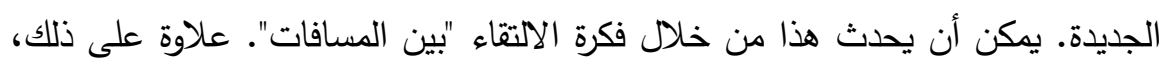
يوضح بابا أنه من أجل تجنب أي نوع من الصدام الثقافي بين المستعمر والمستعمر ؛

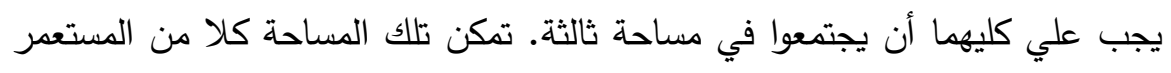

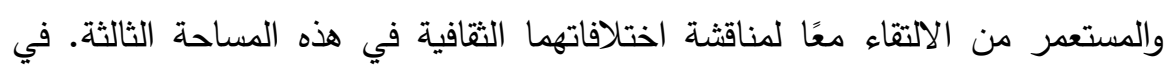
النهاية، سيخلق هذا اللقاء ثقافة هي مزيج من ثقافة المستعمر وثقافة المستعمر • إن الهدف من هذه الورقة البحثية هو التحقيق في كيفية تجسيد كلا من مسرحية فيرديكيا الحدود الأميكية (99T 199) ومسرحية فوجارد سيزوي بانسي قد مات (19VT) لمفهوم هومي ك بابا عن المساحة الثالثة.

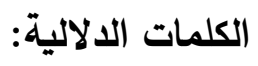
نظرية ما بعد الكولونيالية، هومي. ك. بابا، المساحة الثالثة، جوليرمو فيرديكيا، أتول فوجارد. 
Finding a Third Space: A Postcolonial Comparative study of Verdecchia's Fronteras Americanas and Fugard's Sizwe Basnsi is Dead

Dr. Rasha F.M.Hamza

مجلة وادي التيل للاراسات والبحوث الإنسانية والاجتماعية والتربوية (مجلة علمية محكمة)

Post colonialism is one of the most important theories of the Twentieth Century. It mainly refers to a series of theories and critical approaches that deals with the various attempts to get rid of the legacy of colonialism. The term, also, refers the literature produced by the citizens of the previously colonized countries. Aijaz Ahmed, a well-known postcolonial theorist differentiates in his book, In Theory: Classes, Nations, Literature between two terms: Postcolonial and Post-colonialism. He explains the difference by saying:"postcolonial is simply a polite way of saying not white, not European"(30). Moreover, the hyphenated (postcolonialism/post-colonial) tends to refer to the historical period after a nation has been officially recognized as independent, whereas the non-hyphenated form denotes the consequences of colonialism from the time of its impact. Additionally, R.s. Malik, in his book, A New Approach to Literary Theory and Criticism, also discusses the difference between the hyphenated and the nonhyphenated term saying:

The term Postcolonial(with a hyphen) represents a temporal phase being experienced by those societies which suffered from colonization and are now free, while the term Postcolonial(without a hyphen), connotes much more : it represents a creative mindset and critical approach.(143)

However, the question that imposes itself now is that: have these previously colonized nations really managed to overcome the colonial period? In his book Post-colonial Transformation, Ashcroft thinks that the: 
(ISSN : 2536 - 9555)

Ending of colonial rule created high hopes for the newly independent countries and for the inauguration of a properly

Post-colonial era, but such optimism was relatively short - lived, as the extent to which the West had not relinquished control become clear. (3)

Ashcroft illustrates that in the world after Colonialism and Imperialism, the effects of Colonialism can powerfully be felt in the "subtler forms in the present day exercise of global power" (1). Consequently, whether those previously colonized nations have finally become free, is a matter to be defined on multiple levels. It cannot be decided according to the political and economic level alone, but according to the cultural level as well.

Arif Dirik in The Post-colonial Aura: Third World Criticism in the Age of Global Capitalism highlights three different usages of the term. First, it is used as a "literal description of conditions in the formally colonial societies" (332), secondly, it is used as a "description of a global condition after the period of colonialism" (332); thirdly, it is used of a "discourse on the above named conditions that is informed by the epistemological and psychic orientations that are products of these conditions" (332). Thus, post-colonial means a cultural study of the impact of colonialism on the literature and arts of the previously colonized countries.

However, in The Empire Writes Back, Bill Ashcroft, Gareth Griffiths, and Helen Tiffin employ the term "to cover all the cultures affected by the imperial process from the moment of colonization to the present day" (2). Therefore, postcolonial literature mainly denotes the literary works produced by the excolonies, both before and after they were granted their political independence.

Homi K. Bahabha is one of the most important key figures in the postcolonial theory. He has played a significant role in formulating many concepts in the theoretical discussion of the post-colonial literary discourse. His literary theories of hybridity, 
Finding a Third Space: A Postcolonial Comparative study of Verdecchia's Fronteras Americanas and Fugard's Sizwe Basnsi is Dead

Dr. Rasha F.M.Hamza

$$
\text { مجلة وادي النيل للاراسات والبحوث الإنسانية والاجتماعية والتربوية (مجلة علمية محكمة) }
$$

mimicry, ambivalence, and agency made great contributions to the field of postcolonial cultural studies. His work, The Location of Culture, is regarded as one of the best books that display many aspects of the post-colonial theory. This book investigates the state in which a person can live in a mixed-cultural space. This is a space in which the culture of the colonizer and that of the colonized co-exist. It is in this space of in-betweeness, that a hybrid identity is formed. Moreover, there is what Bhabha calls "The Third Space of Enunciation" (78). It is the liminal space between the cultures of the colonizer and the colonized. According to Bhabha, people should not see colonialism as only a manifestation of oppression, domination, and violence, but as a period of complex and varied cultural contact and interaction. In their book, Classical to Contemporary Literary Theory: A demystified Approach, both Chandra Joseph and Antony Samy define hybridity as:"an important concept in postcolonial theory, referring to the integration (or, mingling) of cultural signs and practices from the colonizing and the colonized cultures"(133).

Hybridity has become one of the most popular concepts in Bhabha's post-colonial cultural criticism. Bhabha has tried to explain the contradictions within the colonial discourse. Bhabha has developed the term cultural hybridity to stress the idea that many authors have sense of belonging to both cultures: the culture of the colonized and that of the colonized. As mentioned in his most famous book, Post-colonial Studies: the Key Concepts, Bhabha's employment of the term, hybridity refers to "the creation of new transcultural forms within the contact zone produced by colonization" (118). In the same way, Ashcroft in his book, Postcolonial Studies: The Key Concepts, states that hybridity is

Celebrated and privileged as a kind of superior cultural intelligence owing to the advantage of inbetweeness, the straddling of two cultures and the consequent ability to negotiate the difference.(158) 
(ISSN : 2536 - 9555)

In The Location of Culture, Bhabha introduces hybridity as type of condition that is created as a result of living between two spaces. He calls this state "Third Space" (78). He explains this by saying that hybridity "is the most common and effective form of subversive oppositions" (29). He defines the situation of hybridity, the condition of being in-between as the "Third Space" (30). It is the space of the hybrids. In this space, differences confront and change each other. In other words, it is the point where two cultures clash and form a third one, which "carries the burden of the meaning of culture" (78). During the interaction between cultures there is a tension in that space, and because of this tension the colonized people fail to create their own social consciousness in the process of decolonization. They only mimic what they experienced, and thus their process of decolonization "merely becomes the replacement of one form of domination by another" (114).

Furthermore, Bhabha's notion of the idea of a third space is that of a place of hybridity. This means, according to Ashcroft et al in Postcolonial Studies: the Key Concepts, that "a culture's difference is ambivalent, ever changing, and open to the possibility of continued interpretation" (17). Hybridity is one of the most common terms in postcolonial studies. It is without doubt indicates "the creation of new transcultural forms within the contact zone produced by colonization" (Ashcroft, 11).The process of hybridization takes many forms, including the cultural, the political, and linguistically. The process of hybridization, in itself, changes the authority and myth of purity of both; the culture of the colonizer and that of the colonized. The hybrid identity is described as "bastard" (Bhabha, 159). Other critics like Sabine Mabardi in the book, Encounters of Heterogeneous kind, argues that hybridity" is a threat to colonial and cultural authority through the ambivalence created by denial, unsettling, repetition, and displacement"(16).

Actually, these strategies used by Bhabha are important for the examination of how the colonized can mimic and locate themselves in the state of in-between cultural space (a third space) 
Finding a Third Space: A Postcolonial Comparative study of Verdecchia's Fronteras Americanas and Fugard's Sizwe Basnsi is Dead

Dr. Rasha F.M.Hamza

مجلة وادي النيل للاراسات والبحوث الإنسانية والاجتماعية والتربوية (مجلة علمية محكمة)

in order to resist ideological and cultural domination of the colonizers. Bhabha does not believe that violence is a way of decolonizing or as a solution of the colonization issue. On the contrary, he believes in the peaceful co-existence between the two cultures; the culture of the colonized and the culture of the colonizer. This will create what he calls a third space of enunciation. In other words, Bhabha wants to say that a national culture can never be pure. It is open to interpretations by the audience. Thus, in the postcolonial discourse, both cultures of the colonized and the colonizer are open to ambivalence. Thus, the two sides, the colonized and the colonizer, in order to gain the meaning of this cultural clash, and meet in between; in a third space, that is neither the space of the colonizer, nor the space of the colonized. Within this third space, the colonizer and the colonized negotiate their cultural differences and create a third space.

Nevertheless, many critics attack Bhabha's ideas. Benita Parry in her book: Postcolonial Theory and Criticism, disapproves of Bhabha as a critic. She believes that Bhabha seeks to "dissolve the binary opposition of colonial self/colonized other"(15), and this enables colonial domination. She, instead, advocates Frantz Fanon who maintains the dichotomy to provide a "dialect of conflict a call to arms"(15). Parry thus criticizes Bhabha's ideas that she believes will disable colonial resistance.

The purpose of this paper is to investigate Homi K Bhabha's concept of "Third Space" in Guillermo Verdecchia's play Fronteras Americanas (American Borders), and Athol Fugard's Sizwe Bansi is dead. Although both plays represent different eras and different countries, they both exhibit the colonized journey from hybridity to finding a third space. The paper also examines the similarities and differences between the two plays.

Fronteras Americanas (American Borders) is a play by Guillermo Verdecchia, who is a Canadian author of fiction and a playwright. He was born in Argentina in 1962, and then he moved to Canada at the age of two. He is also a translator, actor, and 
(ISSN : 2536 - 9555)

director. His play Fronteras Americanas, won the Governor's General's Award. This drama is a semi -autobiographical two-act play, first produced at Tanagon Theatre in 1993. It is a monologue, introduced by only one character, about identity, geography, and the meaning of home. The play tries to portray the sense of loss and alienation of the immigrants. The play has two characters, both performed by the same person. The first character is Verdecchia who reflects the real feelings and life of the playwright. He represents the state of diaspora and loss of identity in the play. Verdecchia was born in a country (Argentina), and brought up in another country (Canada). He has lived most of his life waiting for the day in which he can return to Argentina, where he was born. He believes that he will find his real identity there. Unfortunately, after many attempts and a long journey, Verdecchia, discovers that he does not belong to neither culture of the two. He cannot find his true identity; he never, actually, reaches a decisive realization whether he is a real Canadian, or a genuine Argentinian. Finally, he finds out that he belongs to the boarders, not to a specific place, nor to a definite country. The play also presents the Latin American culture through the other character in the play: the character of Wideload, who represents the Latin-American stereotype.

The play portrays the protagonist's journey to find a third space in which his two conflicting cultures can co-exist together. By doing so, Verdecchia conveys the state of diaspora and searching for a true identity. The play exhibits the status, most of the colonizers; reach on immigrating to another country. He sheds light on the dilemma of an immigrant who losses his own identity, and becomes torn between two cultures. Verdecchia, the playwright and the protagonist of the play, is a man who was born in Argentina, and had to move on to Canada, at a very young age. He lives most of his life in Canada. During the journey of his life, the protagonist dreams of returning to Argentina, where he thinks that he will find his true identity. He feels disoriented and displaced in Canada. He tries to reach a place that he can call home. Verdecchia desires to put an end to his conflict, and to have 
Finding a Third Space: A Postcolonial Comparative study of Verdecchia's Fronteras Americanas and Fugard's Sizwe Basnsi is Dead

Dr. Rasha F.M.Hamza

$$
\text { مجلة وادي النيل للاراسات والبحوث الإنسانية والاجتماعية والتربوية (مجلة علمية محكمة) }
$$

a definite identity, like any other ordinary man. The protagonist goes through an internal conflict because of the confusion and loss of identity. Verdecchia is a representation of what Bhabha calls a hybrid identity. Hybridity is the status of having two different cultures. The protagonist confronts an internal conflict that makes him confused. He wants to belong to only one culture.

At the beginning of the play, the protagonist confesses that he is lost. He says: "I am lost somewhere in my peregrinations on the continent, I lost my way" (Gilbert, 423). He confesses that he has lost his real identity during his journey and nothing can help him now. Even the maps and the compasses cannot help him, as well. The Protagonist keeps on repeating the word"lost", all through the play, for two reasons. The first one is to confirm his feelings of alienation. The second one is to demonstrate the consequences of his feeling of lose and diaspora. Rachel Adams states that:"Early in the play, he laments that he feels lost, although he can locate himself quite specifically in Toronto, at 30 Bridgman Avenue" (321). Verdecchia sets his mind to find a solution to this confusion. He recites stories from his childhood to exhibit his feelings of loss and alienation in the new culture.

My name is next,

Minutes, hours, a century passes as the teacher,

Miss. Wiseman, forces her mouth into shapes hitherto

unknown to the human race, as she attempts to pronounce

my name

Gurilyou-ree moo...Verdeek-

Cheea?

I put my hand up. I am a minuscule

boy with ungovernable black hair,

antennae and gills where everyone else 
(ISSN : 2536 - 9555)

has a mouth.

You can call me Willy, I say. The

Antennae and gills disappear (Act I, 427)

By choosing the name Willy, Verdecchia, tries to mimic the American culture. This is same as what Bhabha states in his book, The Location of Culture: "to be Anglicized is emphatically not being English" (132). Verdecchia feels tired of his state of alienation and wants to go home; he decides to go to Argentina. He takes a long journey, but finally arrives at Argentina, "After an absence of almost fifteen years/ I am going home" (Gilbert, 428). He thinks that his confusion shall disappear, but what really happens is that he faces a deep conflict. He discovers that he does not feel Argentina to be his home. "I just want to go home/ but I'm already there, aren't I?"(Gilbert, Act I, 433). He discovers that Argentina represents nothing more than a place that carries plenty of his memories, just like Canada. Rachel Adams asserts this point of view in her book, stating "he feels no greater sense of belonging in Argentina than he does in Canada" (228). He decides to return to Canada again. "I'm back in Canada". (Gilbert, Act II, 440). He justifies this decision as he wants to return to his work, but the real reason is that he is torn between the two cultures, Verdecchia becomes a hybrid, himself, combining two cultures and two identities. He suffers from an eternal conflict, resulting from feeling different, and never belonging to any place."I am a direct descendant of two people who once ate an armadillo/ Armadillo has a half -life of two thousand years/You can't tell me that is not in my blood stream" (Gilbert, Act I,433). The previous quotation explains how Verdecchia is a hybrid. He combines two different cultures. He is a Canadian citizen by nationality "I am a Canadian citizen." (Gilbert, Act II, 435), and he is a descendent of an Argentinian origins, as he was born there. "I am from Argentina, actually". (437) This multiple identities is what triggered Verdecchia's issue of losing identity and alienation; the problem that can be solved by finding a third space. Verdecchia finds out that he does not belong to a specific country, or to a specific 
Finding a Third Space: A Postcolonial Comparative study of Verdecchia's Fronteras Americanas and Fugard's Sizwe Basnsi is Dead

Dr. Rasha F.M.Hamza

$$
\text { مجلة وادي النيل للاراسات والبحوث الإنسانية والاجتماعية والتربوية (مجلة علمية محكمة) }
$$

culture. Finally, he comes to the realization that he belongs to the borders. The Argentinian - Canadian borders is his own third space. This fact will make him psychologically endorse his reality as an Argentinian -Canadian man. Consequently, he chooses to live on the borders. "I am building a house on the border". (442) The play ends with his decision to live on the border. He cannot have a pure identity till the end. He lives as an Argentinian Canadian man. He endorses two cultures, and carries two identities. The border that he chooses is symbolic of Bahabha's third space. It is the place resulting from the mixture of different cultures. Verdecchia cannot have a pure identity. He becomes torn between two cultures, and he will never be able to belong to one of them and possess one identity, except in this third space: Fronteras Americans, American borders.

Verdecchia: I am learning to live the border...

I am a hyphenated person but

I am not falling apart, I am putting

together. I am building a house on the

borders. I am on the border, I am Home. (Act II, 442)

Another character, in the play, that confronts the same dilemma of a blurred identity is the character of Wideload. Wideload is a Latino man whose real name is Facundo Morales Segundo. "My name is Facundo Morales Segundo" (Act I, 424). He represents the stereotype of a Latino man. He appears in the play wearing a bandit outfit. He narrates his story and explains how he becomes Wideload. When Facundo travelled abroad, the other culture did not accept him, and he felt different. Even his name was strange to them, so, he decided to change it. Rachel Adams explains, in her analysis of the character of Wideload: "the Latino Facundo Morales Segundo, who goes by the ironically adopted Canadian name Wideload McKenna" (228). The playwright employs this character to criticize the idea of stereotyping, and 
مجلة وادي النيل للاراسات والبحوث الإنسانية والاجتماعية والتربوية (مجلة علمية محكمة)

(ISSN : 2536 - 9555)

how every dominant culture does not respect the other. Wideload only attains respect when he changes his name to an Anglo- Saxon one."I go by the name Wideload McKenna/ now and I get a lot more respect"(Act I, 424). Wideload lives on the borders, the same place that Verdeccia chooses to live on. The Dramatist displays the conflict between the Anglo Saxons and the Latino culture. He revels how every nation makes a stereotype of the other culture without knowing it well.

but mostly I just

realized they were a family like any other

wife, crazy aunts and fights and generation

gaps and communication problems two

cars, a VCR, a microwave, a cellular phone

and a dog named Buster ate my socks (427) .

Likewise, Wideload has found a solution to his own dilemma of non-acceptance and stereotyping. Similar to Verdacchia's situation, he has chosen to live on the boarders. The American borders are Wideload's own third space. It represents a place in which he can find peace and solace from cultural clashes.

Similar to employing the concept of a third space in Fronteras Americanas (American Boarders), Athol Fugard implements the same concept in his play Sizwe Basnsi is Dead (1973). Sizwe Basnsi is Dead is a ply written during the Apartheid Era in South Africa. The play discusses giving up identity, which is another impact of colonialism on the individual identity. The play revolves around the story of an African man who decides to give up his identity to continue his life without troubles. Athol Fugard highlights how the colonizers, and their cultural dominance, have destroyed the identity of the black men. Colonization made black people in South Africa believe that their identity is the source of their problems and troubles. Consequently, the only way for them to live in peace and stability is by giving up their own identities. 
Finding a Third Space: A Postcolonial Comparative study of Verdecchia's Fronteras Americanas and Fugard's Sizwe Basnsi is Dead

Dr. Rasha F.M.Hamza

مجلة وادي النيل للاراسات والبحوث الإنسانية والاجتماعية والتريوية (مجلة علمية محكمة)

Black men, under the Apartheid rule in South Africa, were identified by codes, which is much more important than their names, "Burn that into your head, friend. / You hear me? It's more important your name" (187). Each and every black person is controlled by a pass book. This pass book indicates who is this person, and determines where this person should stay or work. Apartheid policy in South Africa destroyed the identity of the blacks. They did not have the right to vote or to be educated. This is clear in the portrayal of the character of Sizwe Bansi, the protagonist of the play who does not know how to read or to write. Bansi comes from King William's Town to Port Elizabeth to find a good job, in order to support his family. Unfortunately, he could not obtain a permit to stay and work at Port Elizabeth. Thus, he was ordered to leave Port Elizabeth immediately. Instead of leaving, he goes to stay with his friend Buntu. Sizwe finds a dead body in the street. This body has a pass book; a long with a work seeker' permit on it. His friend suggests that this is the only option left for him in order to live in Port Elizabeth. He should take the pass book of Robert Zwelinzima. "Sizwe goes back into Robert's book." (183). Although Sizwe refuses at first, he changes his mind and accepts to assume the identity of Robert. Now, Sizwe Bansi decides to eliminate his own identity and assume the identity of a dead man. Sizwe changes his identity because he feels that this identity only causes him troubles. At first he faces a conflict that makes him hesitant to give up his identity. However, the effect of the colonizer is stronger than his hesitation. Bansi, here, reflects the internal conflict that the colonized face, when he is torn between two cultures. One of these cultures has the power and domination, while the other culture makes him weak. Consequently, great number of people from the colonized culture chooses to abandon their own identity, to put an end to their deplorable conditions. Thus, they choose to imitate the culture of the colonizer. The protagonist of the play escapes from being the poor and the weak Sizwe, who cannot stay and work at Port Elizabeth, to be Robert Zwelinzima. Actually, assuming the 
(ISSN : 2536 - 9555)

character of Zwelinzima represents a safe solution for Sizwe. Zwelinzima gives him the opportunity to find a good job, through providing him with the pass book that carries the work seeker's permit.

As a matter of fact, the story of the protagonist of the play, and his act of giving up his own identity, can be discussed in the light of Homi K, Bhabha's notion of a third space. Sizwe's own way to be safe and find his own peace and stability is by complying with the rules and regulations of the colonizer. Now Sizwe faces two cultures: one which is domineering and powerful, while the other is weak and neglected. In order for him to solve this dilemma, he chooses to give up his own identity, and assume an identity; adheres to the rules of the powerful culture. Being Robert Zwelinzima is Sizwe's own third space. The power of the dominate culture is so great that the colonized, in some cultures, has no other choice, but to imitate the colonizer. It is either to fight the dominant power, or to reach a compromise and just live comfortably with the other culture: peaceful co-existence. In the play, Sizwe doesn't choose to imitate the other culture, but rather gives up his own identity. He decides to assume another one, only to escape from the weakness of his own culture. He does not resist, but, on the contrary he chooses to give up and avoid any confrontation with the other dominant culture. He prefers to surrender to the rules and regulations of the colonizer. Actually Fugard, in this play, conveys the consequences of colonialism and how it affects the identity of the colonizer. The colonized main goal becomes finding a third space in which the colonizer and the colonized, can live together in peace and harmony.

On the contrary to this, is the character of Styles. He is a black man who lives in New Brighton, Port Elizabeth, South Africa. He appears in the play holding a newspaper, sitting in his studio, and reading the news to the audience. When he reads the news about the Ford Automobile Company, he starts to narrate his story. First he declares that he was employed as a worker at the Ford Company, before being a photographer. He explains the reasons behind him being a photographer and leaving the company. 
Finding a Third Space: A Postcolonial Comparative study of Verdecchia's Fronteras Americanas and Fugard's Sizwe Basnsi is Dead

Dr. Rasha F.M.Hamza

$$
\text { مجلة وادي النيل للاراسات والبحوث الإنسانية والاجتماعية والتربوية (مجلة علمية محكمة) }
$$

He and all the black workers in the company were treated like monkeys by the white owners. Styles explain how he was working most of his day and only had six hours to sleep."I was right. I took a good look at my life. What did I see? A bloody circus, monkey! Out of every twenty-four hours, I could only properly call mine the six when I was sleeping" (156). He spends most of his day working hard, but he does not get what he deserves. So, he takes the decision of leaving this job, and does whatever he likes.

His decision changes his life forever. Now, he is free and has complete control over his own destiny. Styles chooses to embrace his own identity. The character of Styles is an example of the colonized who resists the regulations of the colonizer. He resists being a follower. He is unlike Sizwe who accepts the surrounding circumstances. Styles resists and changes his life without changing his reality. He preserves his identity and dignity, through taking a job of his own. Working as a photographer is another important part of his character. The dramatist selects this job to criticize the way the world presents an image of the colonized circumstances, through the amplified lenses of a photographer. Fugard wants to proof that the colonizer's image is not always real. For example, Sizwe smiles in his own photo, although in reality, he feels nervous and hesitant. He always presents different stories of different types of people, who come to be photographed. Styles, he refuses to give up his identity, nor to reach a compromise with the other powerful and more dominant culture.

In conclusion, the purpose of this paper is to manifest the impact of colonialism on the individual's identity. People, under the dominance of a powerful culture, would embrace this culture and mimic it, or rather refuse it and never surrender to it. Homi K. Bhabha believes that there is a way: finding a third space. According to Bhabha, a third space is a mid- way two clashing cultures. It is a way of co-existence, between the culture of the colonizer and the colonized. 
مجلة وادي النيل للاراسات والبحوث الإنسانية والاجتماعية والتربوية (مجلة علمية محكمة)

(ISSN : 2536 - 9555)

Both Guillermo Verdecchia and Athol Fugard, are among the playwrights that Bhabha's notion of a third space can be applied to their works. Verdecchia reflects his own experience as being the product of two clashing cultures. Meanwhile, Fugard, represents the status of his community under the Apartheid rule in South Africa. The characters of Verdecchia, and Sizwe Bansi(Robert Zwelinzima) are representation of the colonized strategy of finding a third space to live in. The analysis of the plays: Fronteras Americanas (American Borders) and Sizwe Basnsi is Dead proves that the colonized have different reactions towards the impact of colonialism. The postcolonial Theory proves that colonialism is a major destructive factor of the life and identity of the colonized people. It leads them to lose their identity gradually. The result of this is that a lot of the colonized people lose their identity, and find them in the middle. In this case, the colonized tries to find a third space in which he can embrace the legacy of the two clashing cultures. The border do represent the third space in Fronteras Americanas, where complying to the colonizer's rules and regulations is considered the third space Sizwe Basnsi is Dead. 
Finding a Third Space: A Postcolonial Comparative study of Verdecchia's Fronteras Americanas and Fugard's Sizwe Basnsi is Dead

Dr. Rasha F.M.Hamza

مجلة وادي النيل للاراسات والبحوث الإنسانية والاجتماعية والتربوية (مجلة علمية محكمة)

\section{Works Cited}

Adams, Rachel. Continental Divides: Remapping The cultures of North America. Chicago: The University of Chicago Press, 2009. Print.

Ahmed, Aijaz. Theory, Class, Nations, Literature.London: Verso, 1992. Print.

Ashcroft, Bill, Gareth Griffiths, and Helen Tiffin. The Empire writes Back: Theory and Practice in Postcolonial literatures. New York: Routledge, 1989. Print.

... et al. Postcolonial Studies : Key Concepts. London: Routledge, 1998. Print.

Bhabha, Homi K. The Location of Culture. . London: Routledge, 1994.Print.

Chandra, Joseph and Antony Samy. Classical to Contemporary Literary Theory: A Demystified Approach .India: Atlantic LTD, 2017. Print.

Dirik, Arif, The Post-colonial Aura: Third World Criticism in the Age of Global Capitalism London: Routledge, 1998. Print.

Fugard, Athol. Sizwe Bansi is Dead. New York. Oxford University Press, 1993. Print.

Gilbert, Helen,ed. Postcolonial Plays: An Anthology. New York, Routledge, 2001. Print.

Hiddleston, Jane. Understanding Post colonialism. New York : Routlege, 2014. Print.

Huddart, David. Homi K. Bhabha.. New York : Routledge, 2006. Print. 
مجلة وادي النيل للاراسات والبحوث الإنسانية والاجتماعية والتربوية (مجلة علمية محكمة)

(ISSN : 2536 - 9555)

Loomba, Ania. Colonialism/ Post colonialism. New York: Routledge, 1998. Print.

Malik, R.S and Jagdish Batra. A New Approach to Literary Theory and Criticism. India: Atlantic LTD, 2017. Print.

Parry, Benita. Postcolonial Theory and Criticism. New York: Routledge, 2004. Print. 